HTTP://DX.DOI.ORG/10.12775/SZHF.2017.035

\title{
Bakewell, Sarah. At the Existentialist Café, Chatto \& Windus, London, 2016, pp. 440
}

When we start to discuss existentialism, it is probably impossible to avoid the question of whether existentialism is over or not. I have heard this query since the moment I started to be interested in philosophy, which was almost half a century ago. Recently, I have heard it at a student conference dedicated to existentialism. The conference took place several months ago in Gniezno and was attended by over sixty participants. At that point, I asked: "If existentialism is over, what are you doing here, ladies and gentlemen?"

With this very question about the end of existentialism, Sarah Bakewell begins and also ends her today's popularity record-breaking bestseller At the Existentialist Café (the next bestseller of this well-known populariser of philosophy). On the third page of the core text in the book, how could it not, we find the photographs of Jean-Paul Sartre and Simone de Beauvoir sitting at a café table. After all, existentialism is "a café philosophical belief". I heard that "café existentialists" really existed, also in our country, as early as in the seventies; however, the truth is that in Poland, there has never been any true existentialist in the sense in which Roman Ingarden and his numerous followers were at that time and still are phenomenologists. And the availability of coffee in the forties in the PRL (the Polish People's Republic) was problematic as well. Nevertheless, we could always meet young sensitive people dressed in black sweaters, fascinated by the fundamental questions in the field of human philosophy. They never read philosophical writings by Sartre and Heidegger because these had not been translated into Polish yet. Even if these young people mastered foreign languages at a level enabling them to read philosophical works, they could only dream of having an access to foreign books. Therefore, they read literary works by Sartre, Camus, and Dostoyevsky, and regarding the legendary anthology of philosophical texts 
entitled Filozofia egzystencjalna edited/collected by Leszek Kołakowski and Krzysztof Pomian in 1965, in those days, it was one of the most wanted books that had ever been published in Poland.

To answer my young friends' questions why Kołakowski and Pomian opened this anthology with two separate, critical forewords which heralded the end of existentialism, I can say: "What else could they do? If they had not done it, the book would have never been published."

In times when I studied philosophy, Marxism was a dominant doctrine. Instead of lectures on the history of contemporary philosophy, students were offered the subject named "Marxism and contemporary philosophical beliefs". The then Marxists in Warsaw, similarly to contemporary ones, behaved at the very least strangely. On the one hand, they fully declared themselves to be Marxists, and on the other, they promoted the theory, widely held in certain circles, that Marx was a great wise man; however, he was misread. Therefore, they improved the reception of their idol using Lukács or The Frankfurt School for that purpose. The latter was supposedly considered by the ideologists of the ruling party to be revisionist, but it was of no significance. Likewise, it would not have mattered if, for example, the translations of' works by Heidegger had been published at that time. After all, it would not have been the cause for the Soviet Union to make a military intervention. But the translations were not published for the very simple reason that our Polish party activists themselves liked to ban any publications.

However, although they were neither SB officers nor even party apparatchiks, intellectual Marxists, despite the declaration of freedom of thought and winking at an audience to mean "well, after all, this party should not be taken seriously", detested existentialism. Above all, they always promoted the thesis which, as it turned out later, outlived the PRL: "Existentialism, this movement of café philistines has already ended to exist."

In addition, their claim was substantiated because the death of existentialism was announced as early as in the forties by Sartre who had just a little bit earlier proclaimed himself an existentialist.

In the book by Bakewell, the death of existentialism is presented in two ways. Sartre is right claiming that it was the end of "the café existentialism" associated with a group of people who used to meet particularly in two cafés in a Paris district of St. Germain: Café de Flore and Les Deux Magots. If anyone who had drunk with Sartre his favourite apricot cocktail in one of those cafés had been called an existentialist, the circle of existentialists must have been quite extensive, indeed. In such a case, Pablo Picasso belonged to the 
circle as well as a certain (to use Sartre's favourite name) Pierre who had never created anything but just sat, listened, and enjoyed a famous cocktail. That circle ceased to be the circle of existentialists when Sartre announced that he himself was not an existentialist. It evolved into a different group, and over time, it dispersed like all other "communities of bar pals".

Bakewell perceives the end of existentialism from a global perspective, differently. She states: "When dying Jaspers said..., Heidegger had ordered to be buried next to his parents at the Catholic cemetery, oh, what crowds came to Sartre's funeral!"

Well, everything ends with death, but as Heidegger claims, every end is a beginning. Thus, let us try to answer Bakewell's second, frequently repeated question of how existentialism began, relating it also with the question of what it actually was.

First and foremost, it must be stated that existentialism was meant as the philosophy of existence, and as such, it had functioned before the war, long before anyone heard of Sartre's philosophy. In Poland, we can come across this concept described for the first time in Filozofia egzystencjalna niemiecka by Franciszek Sawicki (See also "Studies in the History of Philosophy 1/2010"), an article published in 1948 but based on the author's much earlier experience. It is devoted to the views of Heidegger and Jaspers whom Sawicki reportedly met in person.

Existence is the key term in Jaspers' and Heidegger's philosophy. It means being me as being one of a kind, incomparable to any other being. This term was coined by Jaspers in his Algemeine Psychopathologie, published in 1913. In this work, he distinguishes existence as the unique fact of being oneself which can never be fully understood but only attempted to be lightened up and captured in the idea, from a character that matches our knowledge of one's spiritual nature to the model which constitutes an element of our systematic perception.

In 1919, Psychologie der Weltanschauungen, the second great work by Jaspers, was published. Heidegger, the author's friend, read it carefully and wrote a review, favourable in tone. He did not publish it, as one might guess, due to probable Jasper's reaction, who was very sensitive to criticism. In both of the works mentioned here, the basic concepts can be encountered (which were used later by Heidegger in Being and Time), especially the triad: being as existence - being-there (Dasein) - opening of the world. Until 1928, i.e. up to the moment of the Being and Time publishing, the philosophers remained very close friends. Heidegger was often a guest in Jaspers' house in Heidel- 
berg where they discussed the manuscript of the work just being written by Heidegger at that time. From that as well as from later periods, numerous Jasper's notes regarding Being and Time have been kept until today. Recognizing a great terminological affinity between Heidegger's and his own thought, Jaspers states that the existential analysis, understood in the way his friend understands it, is definitely impossible. It is only possible to lighten up existence. Heidegger himself later came to similar conclusions, and that is why the second volume of his work was never written.

In 1933, the much-vaunted Nazi episode in Heidegger's life took place; however, Bakewell does not write at length about it. And we should praise her for that. Heidegger's alleged Nazism is "a dinosaur of a claim" from which only few bones have been left, and now it is unknown which are the proper ones. Heidegger, as a vice-chancellor of the University in Freiburg, joined the NSDAP which he never left later, even when he no longer occupied the position of a vice-chancellor. Why? The answer is simple: he did not want to be made redundant, or in the worst case, sent to a concentration camp. As for the famous vice-chancellor's speech - it is written in the spirit and language of the era, and it was in no way about Nazism as such. The language used clearly offends a contemporary reader, but many authors wrote in this manner at that time. The Nazis simply followed this style of expression and adjusted it for their own purpose. Heidegger's memoirs or correspondence with his brother are being examined nowadays for all the information about his supposed Nazi views, with persistence that is surely worth a more important cause. In this case, however, we most often deal with information which comes second-hand (for instance, the popular rumour that Heidegger, being the vice-chancellor, forbade Husserl to enter the university library). The fact remains that, as for Heidegger's Nazi views, there are numerous volumes whose authors refer to some unfavourable rumours with real delight, at the same time, with their characteristic left-wing mannerisms, avoiding other rumours which could counter their criticism. Yet, some facts are plain here. For instance, in 1942, Heidegger delivered lectures on Jasper's philosophy, commenting on it favourably, which was obviously an act of courage (See also my article on this topic in "Studies in the History of Philosophy" 3/2012).

It does not change the fact that, for some time, Heidegger's attitude to Hitlerism and Hitler was marked by a certain lack of foresight. In 1933, visiting Jaspers' home, with his famous words he spoke of the conspiracy of Jewish financiers and of Hitler who had "golden hands". His relation with Jaspers' 
wife who, for some other reasons, had never liked him, was completely damaged by that event.

It does not mean, however, that the cooperation between the two thinkers was entirely suspended. In 1932, when Jaspers' most important work Philosophie was published, Heidegger read it carefully. Unfortunately, his notes taken while reading the work (and of crucial importance for researchers) most probably remained in the manuscript and were unavailable for a long period of time.

And that was a pity. In spite of a considerable difference between the concept of lightening up existence developed in Philosophie and the concept of the existential analysis in Being and Time, once again the content and the terminology used in both works coincide to a large extent. Neither Jaspers nor Heidegger would have ever intended to address the problem of who had borrowed from whom and what. Up to a certain point, they philosophized together. The truth was crucial for them, not the biography.

Sensitive about himself, Jaspers was nevertheless able to be a gentlemen as for writing. He points out, for example, that the idea of a way he perceives existence has been taken from Kierkegaard. This display of modesty departs a bit from the truth because, as Tomasz Kupś investigated thoroughly in the Danish philosopher's works, the term "existence" is rarely used there, and very often the context is not specific. Sartre, however, in his very uninteresting essay Marxism and existentialism, written in the period of his ideological departure from existentialism, interprets these declarations in a truly surprising way. Jaspers himself said that he was not an original philosopher, i.e. he told the truth. Kierkegaard, though being a subjectivist, played a positive role in the history of philosophy, as he at least supplemented Hegel a bit in some issues. Jaspers' views, on the other hand, are a typical example of reactionary ideology, the bourgeoisie calling for improvement of the individual's inner self in order to conceal the necessity of the proletarian revolution.

Bakewell does not include all these issues despite the fact that the aim of her book is to present the nature of existentialism in general, and not just the existentialism of the two cafés mentioned.

We actually find only two short fragments on Jaspers here, but we learn nothing about his philosophy, and nothing about the fundamental and neverexplored Jaspers and Heidegger's mutual influence of thoughts. About Heidegger himself, we can read a bit more, but not too much. We found out, for example, that during his one and only meeting with Sartre in Freiburg Baden, they had nothing to discuss. Their conversation began with paying 
compliments to each other and ended with telling jokes. We read a little more about Husserl in Bakewell's book, and rightly because Sartre considers his first works, Being and Nothingness and especially his earlier essay Imagination a continuation of phenomenology. Nevertheless, even in Bakewell's book, it is clear that what Sawicki calls German existentialism and that what we call Parisian existentialism (of which the basic terms for Bakewell are freedom, being, and apricot cocktail) are both linked only with "a narrow footbridge over the abyss".

In 1933, Sartre arrives at Berlin for a one-year scholarship. He is fascinated with Husserl, but he does not go to Freiburg to meet his idol. What is more, when Husserl delivers a lecture in Berlin, unfortunately, Sartre and Beauvoir cannot attend it. Why? Bakewell does not explain this commenting only on Sartre's fondness for the good German law at that time.

Both of Sartre's first well-known works are actually characterised by a clear reference to the phenomenological method. And what about French existentialism? This is probably Gabriel Marcel's invention who supposedly stated that existentialism was divided into atheistic, practised by Sartre and Heidegger, and Christian, represented by Jaspers and Marcel himself. Obviously, it was, in the vernacular, a far-fetched division. Neither Jaspers was a Christian thinker nor Heidegger an atheist. They both lived "outside religion" and were formally considered Protestants. They both also shared the opinion that the question about God, not arising from any empirical necessity, and nevertheless necessary, was transcendental.

In Existentialism is humanism, Sartre however accepts this absurd division "with the benefit of inventory". And it is when a very short but also very turbulent period of "café existentialism" begins. Sartre himself is its unquestionable guru, and the muse is Simone de Beauvoir who, to be honest, was neither an existentialist nor a philosopher. Win her case, when filling a form, in the "Occupation" space one would just be best to write: Simone de Beauvoir. From among professional philosophers, Marianne Merleau Ponty landed herself, if such a colloquial phrase may be used here, to this group. From among writers we can include Albert Camus who always distanced himself from such a classification. Who else as an existentialist draws Bakewell's attention? From among those more renowned, one can mention Boris Vian, a writer, but supposedly a better trumpeter; Arthur Koestler, a leftie deprived of his national identity who at first accepted the historical necessity of famine caused by the Bolsheviks, then later converted, to finally commit suicide; or a provocateur and drug addict Jean Genet, mainly the author of his own 
biographies. Similarly, as we also learn from Bakewell's book, existentialism was a fashion in America. Well, a certain Mailer Norman founded an existentialist party on behalf of which he wanted to run for the mayor of New York, but finally gave up after he had seriously injured his wife stabbing her with a knife. It is interesting enough, given that there are no American existential philosophers known to the public. As Jaspers puts it:

"When in Paris, a young man dresses eccentrically, he enjoys erotic freedom, does not work, spends his life in a café and makes quirky parodies, is said to be an existentialist, half a century ago in Berlin a young man of similar lifestyles would become an unspoken man. And yet the former has little to do with Sartre, as the other had with Nietzsche."

Jaspers was only partially right. Sartre, being undoubtedly a great philosopher, was at the same time that very one, superannuated young man described by Jaspers. This kind of thinker-eccentric is a phenomenon typical of Paris of those times. Derrida also resembled Sartre, though he was not a great philosopher but rather a postmodern eclectic.

Interestingly enough, from Bakewell's work, one can find out very little about the philosophy of Marcel who played an outstanding role in the existentialism formation process in France. The name of Mounier, the author of a widely-known book Existentialist Philosophies or of Maritain are not mentioned in her book at all.

Finally, we will even find here no reference to such important cultural phenomena as Russian existentialism the chief representatives of which, Bierdiev and Szestov, also worked in Paris long before Sartre, or for instance existentialism in Spain with a "fascist" Unamuno, to name just one. The reason for this appears to be quite obvious. They made no ideology out of sitting in cafés, they made no issue of their unusual sex life, and above all, they were all thinkers embedded in Christian culture.

When my assistant, Marta Chojnacka, was reading some of Heidegger's works in a library in Paris, someone asked her: "How can Heidegger be read by anyone, he is a Nazi, isn't he?" Such a person would not probably mind Sartre's fascination with the Stalinist communism, and his later conversion to...Maoism and parading in Paris in a hongweibing uniform. Yet, each of these regimes cost more human beings murdered and starved than Nazism itself. Probably the most curious phenomenon in this regard was the regime

${ }^{1}$ Jaspers, K. Czym jest egzystencjalizm? [What is existentialism?], transl. Staniewska, A. in Rudziński, R. Jaspers, Warsaw 1978, p. 269. 
of Pol Pot who was educated in France. Despite all the above mentioned, up to this day, one can encounter those "old existentialists", and (nowadays) postmodernists, deconstructivists, or simply lefties who claim that Marxism itself was good but its ideology has not been adopted in its proper form yet.

That kind of communism was not communism at all. The Communist Manifesto was not written by Marx but by Charles Darwin, I guess. On the other hand, the thesis "Those who disagree with us should be eliminated" is understood differently by different lefties - either it is not present in Marx's works at all or it is right and consistent with the ideas of some imagined, betrayed democracy.

For a short period of time, a certain fraction of the Parisian leftism used the word "existentialism" as their own name; however, they quickly ceased to do it because of the reason which Jaspers again remarkably describes: "Existential philosophy can be valued as an attempt to overcome nihilism"2.

In the case of leftism, it is nihilism that becomes a weapon in the fight which is itself a fundamental issue, since everything which is evil in the world is that way due to ill will and malice of reactionary forces. The warriors who take part in this fight have a vague vision of what this bright future which they fight for will look like. In this regard, they often behave like Lenin who blathered that communism was the power of councils plus electrification.

Recently, certain Polish social circles have esteemed a political figure named Mateusz Kijowski, a superannuated young man parading in a red jacket, with several earrings in his ear and long hair tied in a ponytail. From the beginning, it was widely known that he evaded paying alimony; however, it did not bother his devotees among whom celebrities, well, even feminists, could be found. Kijowski was the founder of the so-called Committee for the Defence of Democracy. Being a leader of the committee he was, finally accused of fraud.

The slogan propagated during that Committee manifestos was "freedom, equality, and democracy". It was a distortion of the Enlightenment-era concept that freedom, equality, and brotherhood are the very foundations of democracy. So far, no one has noticed the absurdity resulting from the misrepresentation of the slogan. And it is the absurdity of the same type as if one were to replace the thesis "The three physical states of matter are: gaseous, liquid, and solid" with the thesis "The three physical states of matter are gaseous, liquid, and material".

\footnotetext{
2 Ibid., p. 274.
} 
The brotherhood, which is what Jaspers called existential communication, has always been out of the way of leftism opponents. Sartre, who knew what that communication was, quickly forgot the fact after the Second World War.

Following Bakewell's, whose bestseller will soon be translated into Polish and published, I would suggest that the slogan

"Freedom - equality - democracy"

should be replaced with the slogan

"Freedom - equality - apricot cocktail".

Still talking nonsense but at least it allows to avoid the effect of a vicious circle.

Mirosław Żelazny

Nicolaus Copernicus University, Toruń, Poland e-mail: zelazny@umk.pl 